Pamiętnik Literacki 2019, 1, s. 43-55

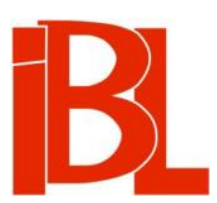

\title{
Inna opowieść o wojnie. "Czyste mieszkanie” Hanny Malewskiej
}

\author{
Aleksandra Chomiuk
}


Pamiętnik Literacki CX, 2019, z. 1, PL ISSN 0031-0514

DOI: $10.18318 / \mathrm{pl} .2019 .1 .3$

ALEKSANDRA CHOMIUK Uniwersytet Marii Curie-Skłodowskiej, Lublin

\section{INNA OPOWIEŚĆ O WOJNIE „CZYSTE MIESZKANIE” HANNY MALEWSKIEJ}

Na tle historycznej prozy Hanny Malewskiej swoim tematem wyróżnia się opowiadanie pisarki poświęcone konspiracji z czasów drugiej wojny światowej. Data umieszczona w jego ostatecznej wersji: „VII 1954”, wskazywałaby na rocznicową motywację tekstu (dziesięciolecie wybuchu powstania warszawskiego). Jak jednak ustalił Andrzej Sulikowski na podstawie materiałów z archiwum autorki znajdujących się w Bibliotece Jagiellońskiej, Czyste mieszkanie rodziło się przez kilka powojennych lat, a pierwsze ślady pracy nad nim pochodzą z $1948 \mathrm{roku}^{1}$. W rezultacie utwór dotarł do czytelników dopiero 6 dekad później dzięki drukowi w miesięczniku „Znak”. Po kolejnych 8 latach tekst został opublikowany w wyborze opowiadań Malewskiej, na który złożyły się jeszcze trzy przedruki z wcześniejszych zbiorów: Rodzina - z tomu Stanica. Opowieści rzymskie (1947); Sir Tomasz More odmawia i Koniec Cranmera - ze zbioru Sir Tomasz More odmawia (1956).

Tytułowe mieszkanie to jeden $\mathrm{z}$ warszawskich lokali, w którym działała komórka szyfrów korespondencji zagranicznej Wydziału V Komendy Głównej AK. Opowieść ukazuje codzienna prace grupy szyfrantek od chwili, kiedy pojawia się podejrzenie, że Chlewik - jak nazwano owo miejsce ze względu na bliskość gospodarstwa SS-manów - został zdekonspirowany i kobiety muszą znaleźć nowe, bezpieczne lokum, aż po ich powrót do starego mieszkania.

Opowiadanie to ogniskuje kilka problemów istotnych z perspektywy opisu całej twórczości autorki Żniwa na sierpie. Przypominając nieodległe wydarzenia okupacyjne, wiąże się $\mathrm{z}$ jej powstającymi w latach czterdziestych XX wieku wypowiedziami publicystycznymi dotyczącymi czasu wojny. Stanowi odwołanie do okoliczności pracy konspiracyjnej Malewskiej i po raz kolejny ujawnia swoistość autobiografizmu pisarki, która oszczędnie dawkuje informacje o sobie. Wreszcie tekst syntetyzuje faktograficzne odniesienia do okupacyjnych realiów z czysto literackimi środkami ich przedstawienia, przesuwając równocześnie zainteresowanie z porządku zdarzeniowego na zapis wojenno-okupacyjnych doświadczeń jako wieloaspektowej sytuacji, z którą musi zmierzyć się jednostka.

Wyznaczoną wyszczególnionymi tu genetyczno-biograficznymi tropami lekturę Czystego mieszkania chciałabym zacząć od zasygnalizowania jego związków z wcześ-

1 A. Sulikowski, wstęp: Osobliwości opowiadań Hanny Malewskiej. W: H. Malew s ka, Opowiadania. Kraków 2015, s. 17. Dalej do Opowiadań odsyłam podając w nawiasach numery stronic. 
niejszą publicystyką Malewskiej dotyczącą okupacji i jej skutków. Otóż na tle nie tak znowu obszernej, bezpośrednio powojennej refleksji na ten temat ${ }^{2}$ teksty autorki Żelaznej korony zwracają uwagę swoją dwutorowością, pragmatycznym odniesieniem do takich m.in. problemów, jak negatywny wpływ wydarzeń z lat 1939-1945 na ludzkie postawy, konieczność wzmocnienia działań pedagogicznych wobec młodego pokolenia czy też potrzeba sprawiedliwego podziału dóbr w zubożonym po 1945 roku społeczeństwie przy jednoczesnym odwoływaniu się do imponderabiliów ${ }^{3}$. Istotny w kontekście historycznych rozliczeń wojennych jest głos Malewskiej dotyczący heroizmu bohaterów Conradowskich, stanowiący polemikę z odczytem Jana Kotta wygłoszonym w czerwcu 1945 w krakowskim Związku Literatów ${ }^{4}$. Ów spór o Conrada był tak naprawdę zderzeniem dwu postaw ideowych: pragmatyzmu, stawiającego na pierwszym miejscu racje rozsądku, oraz idealizmu, odwołującego się do wierności wartościom moralnym bez względu na cenę. Obrończynią etyki Conradowskiej była w tej dyskusji m.in. Maria Dąbrowska, kwestionująca zarzuty kierowane przez Kotta w stosunku do żołnierzy Polski Podziemnej, dotyczące ich ślepego przywiązania do przebrzmiałych i skompromitowanych idei ${ }^{5}$. Prezentowana przez Conrada postawa absolutyzmu moralnego stanowiła, zdaniem autorki Nocy i dni, konieczność w sytuacjach granicznych, kiedy to wartości etyczne stają się jedynym gwarantem człowieczeństwa ${ }^{6}$. Malewska w swoim tekście, opublikowanym kilka miesięcy wcześniej w stosunku do artykułu Dąbrowskiej, wykorzystała - najogólniej ujmując - podobny jak u tej pisarki kierunek argumentacji, bardziej jednak ambiwalentnie odnosząc się do samej postawy przyjmowanej przez Conradowskich bohaterów. Autorka Czystego mieszkania pisała bowiem:

U Conrada motywy heroizmu są za słabe nie tylko z punktu widzenia użyteczności, ale też i w skali „imponderabiliów”. Da się on istotnie sprowadzić do heroizmu honoru. Honor zaś jest wartością irracjonalną i konwencjonalną. [...]

Tym niemniej heroizm ludzi Conrada jest czymś, co wykracza poza - przypuśćmy - elegancka śmierć w pojedynku XVII-owiecznego markiza. Bo wyrażają się w nim instynkty etyczne, które przyjeły na siebie tę formę w braku wyższej, ale ostatecznie ją rozsadzają, dochodząc na pogranicze zupełnego irracjonalizmu. [...]

Wartość wychowawcza takiego stanowiska? Oczywiście negatywna, o ile Conrad miałby zaszczepić kult samobójczego bohaterstwa dla bohaterstwa. Pozytywna, jeśli z niego wyciagniemy dalsze wnioski: o istotnym podłożu natury ludzkiej, która chwyta i ubóstwia podrzędne ideały dlatego, że bez ideału obejść się nie może ${ }^{7}$.

Zob. M. Zaw odniak, Wojna $w$ tużpowojennym dyskursie społeczno-literackim. W zb.: Wojna i postpamięć. Red. Z. Maj chrowski, W. Owczarski. Gdańsk 2011.

3 H. Malew s ka: Do kogo mówimy. „Odrodzenie” 1945, nr 5; Miłosierdzie. „Tygodnik Powszechny” 1945, nr 3; To, co najważniejsze. Jw., nr 16; Hierarchia. Jw., 1946, nr 8.

4 Odczyt opublikowano jako artykuł zatytułowany O laickim tragizmie Conrada („Twórczość” 1945, $\mathrm{nr}$ 2), następnie przedrukowano w poszerzonej wersji w książce J. Kotta Mitologia i realizm. Szkice literackie: Tacyt, Stendhal, Gide, nadrealiści, Conrad, Malraux (Warszawa 1946).

5 M. Dąbrow s ka, Conradowskie pojęcie wierności. „Warszawa” 1946, nr 1.

6 Więcej na temat tej polemiki w kontekście pokoleniowego zróżnicowania stosunku do Conradowskich imponderabiliów zob. P. Ro d a k, Pokolenie 1910, pokolenie wojenne i spór o Conrada. W zb.: Formacja 1910. Świadkowie nowoczesności. Red. D. Kozicka, T. Cieślak-Sokołowski. Kraków 2011.

7 H. Malews ka, Jeszcze o heroizmie. „Tygodnik Powszechny” 1945, nr 15, s. 6. Warto dodać, że 
To warunkowe trwanie po stronie autora Lorda Jima ujawniaja i późniejsze wypowiedzi Malewskiej poświęcone powstaniu warszawskiemu, w których ocena tego wydarzenia w kategoriach straceńczej wielkości łączyła się z lękiem przed kolejną hekatomba prowadzaca do unicestwienia narodu:

A takiej krwi nie wolno światu jeszcze raz wytoczyć na bruk, bo zginiemy ${ }^{8}$.

Czy tak daleko idąca „warszawizacja” oblicza narodowego i polityki polskiej nie była czymś niebezpiecznym? Chyba tak, była. I dla Polski, i dla Warszawy. Ale to już inna, wielka sprawa ${ }^{9}$.

Z jednoczesności dwu postaw, poczucia obowiązku, od którego nie wolno było się uchylić, przy dostrzeżeniu wszakże rozmiaru strat i zniszczeń, wypływały też słowa, które warto mieć w pamięci w trakcie lektury opowiadania jako świadectwa okupacyjnej wiedzy i świadomości:

jeśli chodzi o problem Powstania, to właśnie ci, co je [...] przeżywali, najdalsi są chyba od podtrzymywania trady cji krwawych i bohaterskich szaleństw. [...] To był szczyt pewnych możliwości ludzkich, pewnego typu wielkości, nawet gdyby świat nie przemienił w rok potem oblicza w łunie Hiroszimy byłoby to nie do powtórzenia. A ponieważ przemienił, ta karta historii zamknęła się definitywnie. To, co było tragicznym porywem, powodowanym pewną tragiczną logika, zmartwychwstałoby jako krwawy nonsens - a nonsensy nie należą już do królestwa tragiczności ${ }^{10}$.

Kolejnym istotnym kontekstem utworu jest jego autobiografizm, mocno wyeksponowany przez Annę Głąb w książce poświęconej Malewskiej ${ }^{11}$. Należy jednak podkreślić, że ujęty on został w sposób specyficzny i odległy od tego rozumienia, które utrwaliło się za sprawą Philippe’a Lejeune'a. Gdyż brak tu podstawowej cechy, jaką francuski badacz powiązał $\mathrm{z}$ paktem autobiograficznym, utożsamienia autora, narratora $\mathrm{i}$ bohatera opowieści ${ }^{12}$. Malewska nie tylko bowiem stosuje zmienną perspektywę narracyjna, ale i wprowadza kilka równorzędnych bohaterek, nie pozwalając jednocześnie na biograficzną identyfikację żadnej z nich. Jak też czytamy w zamykającej Czyste mieszkanie notce:

pisarka odniosła się również w odrębnym tekście do całej książki Kotta i jego krytycznej diagnozy europejskiego humanizmu. Zob. H. Malew s k a, Dwa widnokręgi. Jw., 1946, nr 29.

H. Malew sk a, Pożegnanie. „Znak” 1946, nr 2 (luty), s. 143.

9 H. Malewska, Dlaczego właśnie Warszawa (wypowiedź w ankiecie). „Kalendarz Warszawski” 1948. Przedruk w: O odpowiedzialności i inne szkice. Wybór publicystyki (1945-1976). Przygotowanie, wstęp A. Sulikowski. Wyd. 2, zmien., poszerz. Kraków 1987, s. 424.

H. M a le w s k a, Jeszcze o „Rozwalonym domu”. „Tygodnik Powszechny” 1946, nr 47, s. 6. O konspiracji i powstaniu warszawskim wypowiadała się pisarka również w innych tekstach publicystycznych, takich jak: Rocznica (Jw., 1945, nr 19) czy Sierpień i wrzesień („Twórczość” 1945, nr 1). Kontynuacją nurtu rozważań na temat postaw heroicznych są dwie publikacje $\mathrm{H}$. Malew ski j (Realizm. „Tygodnik Powszechny” 1946, nr 49; Jeszcze o kulcie heroizmu wojennego. Jw., 1947, nr 10), dotyczące artykułu A. B o c h eń s k i e g o O dyskusji nad Monte Cassino (Jw., 1946, nr 45).

11 A. Głą b, Ostryga i łaska. Rzecz o Hannie Malewskiej. Kraków 2009, s. 84-93.

12 Zob. Ph. Lejeune, Pakt autobiograficzny. Przeł. A. W. Labuda. „Teksty” 1975, nr 5, s. 31. Również w kolejnych pracach francuskiego badacza - mimo dokonywanych przez niego rozmaitych rewizji dotyczących m.in. zjawiska referencyjności autobiografii - owa możliwość utożsamienia pozostaje sednem zobowiazania autobiograficznego (zob. Ph. Lej e u n e: Czy można zdefiniować autobiografię? Przeł. R. Lub a s-Barto szyńska; Pakt autobiograficzny 〈bis〉. Przeł. S. J awor ski; Autobiografia $w$ trzeciej osobie. Przeł. S. J a wors ki. W: Wariacje na temat pewnego paktu. O autobiografii. Red. R. Lu b a s-B a r to s zy ń s ka. Kraków 2001). 
Opowiadanie niniejsze nie jest kroniką. Osoby nie są portretami, raczej rozszczepieniem, krzyżówką lub aluzją do pierwowzorów. Może wynika z tego portret zbiorowy komórki, także jednak niekompletny. [s. 350]

Tę niechęć do nadmiernego odsłaniania ,ja” można próbować objaśniać powojenną polityką komunistycznej władzy i represjami wiążacymi się $\mathrm{z}$ ujawnieniem konspiratorskiej działalności w Armii Krajowej. Przeszkody natury polityczno-cenzuralnej bardziej jednak tłumaczą brak podjęcia przez pisarkę starań o publikację tekstu. Sama natomiast rezygnacja $z$ autobiografizmu stematyzowanego, bezpośrednio wskazującego relacje między fabułą opowiadania a wydarzeniami $z$ życia jego autorki ${ }^{13}$, ma - jak sądzę - inne podstawy. Problem leży bowiem również w wyraźnej nieufności wobec literatury jako medium osobistej konfesji. Jest to przecież widoczne także w książce najbliższej formule opowieści (auto)biograficznej, w Apokryfie rodzinnym, stanowiącym tyle genealogie samej Malewskiej, ile - jak czytamy w nim - „dzieje rodzinne co drugiego inteligenta” jej pokolenia ${ }^{14}$. To właśnie w kontekście Apokryfu rodzinnego Inga Iwasiów podkreślała „metodę tego pisarstwa, obdarzającego zaufaniem wiedzę, bibliotekę, literaturę, wycofującego natomiast na drugi plan świadectwo osobiste"15.

W opowieści poświęconej pamięci rodowej Malewska korzysta $z$ wszystkich odmian niefikcjonalnego dyskursu: dokumentalnego, eseistycznego i autobiograficznego ${ }^{16}$, dokonując jednak ich swoistego przetworzenia. Dokumentaryzm zostaje podszyty apokryficzną fikcja, eseistyczność zyskuje wartość refleksji autotematycznej i metahistorycznej, autobiografizm zaś nie łączy się z wyznaniem. Stanowi on raczej proces rozpoznawania i kształtowania własnej tożsamości w odniesieniu do wzorów zewnętrznych, odwołujących się do kanonu polskiej pamięci zbiorowej. Warto też zwrócić uwagę na to, iż zgodnie $z$ tym kanonem podział ról w Apokryfie rodzinnym jest tradycyjny, wojna to rzecz męska, do zadań kobiet natomiast należy dbałość o dom i wychowywanie kolejnych pokoleń żołnierzy sprawy narodowej. Podkreślmy przy okazji, że mamy tu do czynienia ze zjawiskiem odmiennym od dominującej we współczesnym dyskursie memorystycznym prywatyzacji pamięci, wiążącej się - według Andrzeja Szpocińskiego - z postępującym procesem autonomizacji pamięci lokalnej: rodzinnej i wspólnotowej, w stosunku do tradycji ogólnonarodowej ${ }^{17}$.

Ucieczka od konfesyjnej formuły charakteryzuje również opowiadanie ukazujące codzienność działań konspiracyjnych w okupowanej przez Niemców Warszawie. Zamiast jednak apokryficzności autorka wykorzystała zabieg wielokrotnego portretu, który zaciera granice między tym, co indywidualne, a tym, co wspólnotowe ${ }^{18}$. artystyczna. Na materiale wspótczesnej prozy polskiej. „Pamiętnik Literacki” 1988, z. 4, s. 87).

H. Malews ka, Apokryf rodzinny. Wstęp, oprac. A. Sulikow s ki. Kraków 1997, s. 49.

I. I w a s i ó w, Kultura apokryfu. „Znak” 2013, nr 694 (marzec). Na stronie: http://www.miesiecznik. znak.com.pl/6942013inga-iwasiowkultura-apokryfu/ (data dostępu: 2 XI 2016).

Są to odmiany dyskursu niefikcjonalnego, o których pisał R. Ny c z w artykule Literatura nowoczesna: cztery dyskursy (tezy) („Teksty Drugie” 2002, nr 4).

A. Sz p o c iń s ki, O wspótczesnej kulturze historycznej Polaków. W zb.: Przemiany pamięci społecznej a teoria kultury. Red. B. Kor ze ni ew s ki. Poznań 2007.

Ten aspekt autobiografii kobiecych, w których częstym zjawiskiem jest „napięcie między poczuciem 
Własna historia Malewskiej i historie cudze zostały bowiem splecione tak, by czytelnik nie był w stanie owych pasm rozdzielić. Pomieszanie losów nie tylko utrudnia rozpoznanie tropów biograficznych, ale i łączy się z uniwersalizacją postaw zgodnie z tym, co po latach pisał o sytuacji okupacyjnej Janusz Sławiński:

konspiracja to nie tylko układy osobliwych realiów socjopsychologicznych, czasowo i geograficznie zlokalizowanych; to zarazem modelowe sytuacje zagrożenia, lęku, solidarności, odpowiedzialności, które przez swą graniczność skłaniają do interpretacji egzystencjalno-antropologicznych ${ }^{19}$.

Jeśli więc Sulikowski zwracał uwagę na quasi-reportażową technikę opowiadania przywołującego atmosfere konspiracji ${ }^{20}$ oraz rekonstruującego „portrety rzeczywistych działaczek podziemia" (s. 19), to aspektem przynajmniej tak samo istotnym jak wspomniana referencjalność - rzec by można - zewnętrzna, jest u Malewskiej przeświadczenie o konieczności ukazania wymiaru egzystencjalnego dziejów w kontekście tego, co dałoby się określić mianem przeżycia historycznego. Owo przeniesienie zainteresowania $\mathrm{z}$ faktografii na sposób postrzegania rzeczywistości łączy się $z$ wykorzystaniem takich m.in. chwytów, jak cząstkowe, personalne ujęcia rzeczywistości, werbalizowanie doświadczeń bohaterów w formie mowy zależnej i pozornie zależnej, ograniczanie wiedzy o finale zdarzeń, a nawet jej przesunięcie do paratekstu ${ }^{21}$ oraz wzmocnienie fabułotwórczej roli dialogów. Dialogi zostają także prawie zupełnie pozbawione narratorskiego wsparcia, co skutkuje tym, że jak pisała o podobnych zabiegach Teresa Cieślikowska - „fakty powieściowe i toczące się pomiędzy bohaterami rozmowy same bezpośrednio informują czytelnika o świecie przedstawionym [...]"22.

Przypomnijmy przy okazji - w odniesieniu do dialogowej konstrukcji utworu, że Malewska zastosowała ją też w dwu opowiadaniach historycznych powstałych w pierwszej powojennej dekadzie. Taki charakter ma Rozmowa pod Ariminum tekst $n b$. także odnaleziony w papierach pisarki, wydany dopiero po jej śmierci ${ }^{23}$ oraz Spowiedź $w$ Saint-Germain-des-Prés ${ }^{24}$. W Czystym mieszkaniu nie mamy jednak do czynienia z powielaniem konwencji literackiej. Zarówno Rozmowa, jak

własnej wyjątkowości” a „poczuciem wspólnoty z innymi kobietami” eksponowała S. St a n for d Friedman w artykule Women's Autobiographical Selves: Theory and Practice (w zb.: Women, Autobiography, Theory. A Reader. Ed. S. Smith, J. W at s o n. Madison, Wis., 1998, s. 79).

J. Sła wi ńs ki, Zaproszenie do tematu. W zb.: Literatura wobec wojny i okupacji. Studia. Red.

M. Głowiński, J. Sławiński. Wrocław 1976, s. 9.

20 Zob. ibidem, s. 17

21 Chodzi o zamykającą utwór dedykację (s. 350):

$$
\begin{aligned}
& \text { Poległym: } \\
& \text { „Zanci” - Halinie Dadejowej } \\
& \text { „Ewie” Stefanowskiej } \\
& \text { „Mariszce” Koźmińskiej } \\
& \text { Z „Karolinek”, zwanych później } \\
& \text { „Bajką, „Przedszkolem”, „Konsulatem”, z V KG AK. }
\end{aligned}
$$

T. Ci eśli k o w s k a, Tendencje do teatralizacji w powieści współczesnej. (Wstęp do problematyki). W zb.: Styl i kompozycja. Konferencje teoretycznoliterackie $w$ Toruniu i Ustroniu. Red. J. Trzy n adlow ski. Wrocław 1965, s. 290. 
i Spowiedź wykorzystują dialog do historiozoficznego rozliczenia, podporządkowują go pytaniom o możliwości wpływania na dzieje ${ }^{25}$. Natomiast w utworze okupacyjnym zapisy rozmów bohaterek stanowią sposób zaprezentowania czytelnikowi działań konspiracyjnych, pomagają wczuć się w atmosferę okupacyjną, ujawniając równocześnie wspólnotowe (kobiece) metody na rozpraszanie wojennych lęków i traum.

Przyjmowanie takiej perspektywy: partykularnej i fragmentarycznej, pozbawionej oparcia w narratorskiej wszechwiedzy, byłoby - w aspekcie pytań o fakty - postrzegane $z$ dużą dozą nieufności. W tym jednak przypadku ów zabieg pozwala na dotknięcie istoty doświadczenia wojennego, o którym następująco pisał Krzysztof Zaleski:

Wojenny świat przedstawia się zamkniętemu w jego wnętrzu podmiotowi jako chaos faktyczności; niespoista lub co najmniej dychotomiczna, całościowo nieogarnialna lawina zdarzeń wypełniająca czas wciąż nieprzeszły, nie przejrzany ostatecznie, rozdrobniony na momentalne sekwencje niespodziewanych zmian i stanów - stawia silny opór wszelkim wysiłkom globalizacji jej sensu ${ }^{26}$.

Zadaniem opowieści nie jest zatem po prostu odpowiedź na pytanie: ,jak było naprawdę?" Rekonstrukcja rzeczywistości wojennej odnosi się w utworze zarówno do trybu działania warszawskiej komórki szyfrów, jak i do sensów przypisywanych wydarzeniom przez ich uczestniczki.

Zamiast wielkiej narracji okupacyjnej $\mathrm{z}$ jej nadrzędnym auktorialnym dysponentem Malewska wprowadziła opowieść mała, co można odczytać na kilka sposobów. Chodzi bowiem nie tylko o wybór gatunku literackiego ${ }^{27}$, ale i o przesunięcie od przeszłości historycznej ku - jak to ujmuje Hayden White - praktycznej, która rozumie on jako zastapienie zobiektywizowanego zespołu zdarzeń dających się usytuować w określonym czasie i miejscu obrazem konkretnych postaw i działań zachowanych „w formie pamięci, wyobraźni, strzępów informacji, formuł, zrytualizowanych zachowań czy mglistych wyobrażeń na temat "historii""28; a także o lokalność w wymiarze przestrzennym związaną z brakiem odwołań do światowego teatru wojny czy wreszcie o wybór kobiecej perspektywy narracji. Bohaterki utwo$\mathrm{ru}$ występują tu w rolach innych niż w tradycyjnych opowieściach militarnych, w których bojownicy i konspiratorzy to mężczyźni, kobietom zaś wyznacza się funkcje zaledwie pomocnicze. Szyfrantki u Malewskiej nie tylko sa postaciami pierwszoplanowymi w porządku fabularnym, ale zostaja dowartościowane w perspektywie historycznej. To od ich inteligencji, staranności, uporu i odwagi zależy bowiem powodzenie działań militarnych.

Fabularyzacja nie zmierza też do nadania zdarzeniom charakteru całościowego z Arystotelesowskim początkiem, środkiem i końcem, lecz stanowi kronikarskie

Pisałam o tym szerzej w książce Od mitu do antyutopii. Historiograficzna wyobraźnia Hanny Malewskiej (Lublin 2017).

26 K. Zale s ki, Fakt i sens całości. W zb.: Literatura wobec wojny i okupacji, s. 125.

27 Należy jednak dopowiedzieć, że sama koncepcja utworu podlegała w trakcie pisania ewolucji i na początku najprawdopodobniej miał on być bardziej rozbudowany. Świadczy o tym zachowany plan Czystego mieszkania, który przedstawia Sulikowski we wstępie do jego książkowego wydania.

28 H. White, Zdarzenie historyczne. W: Proza historyczna. Red. E. D o mań ska. Kraków 2009, s. 253 (przeł. R. Borysławski). 
pars pro toto ${ }^{29}$. Jeśli przestrzeń zostaje od początku doprecyzowana (jak zauważył Sulikowski: „Wszystkie ulice i zaułki wymieniane w opowiadaniu są autentyczne, łatwe do odnalezienia na mapie Warszawy, nawet dzisiejszej” 〈s. 19〉), to już czasu zdarzeń nie dookreśla się ani w odniesieniu do ich rozciagłości w zakresie porządku fabularnego (można tylko przypuszczać, że chodzi tu o kilka miesięcy), ani wobec kalendarza historycznego. Oczywiście, niepodważalną dziejową ramę stanowią lata niemieckiej okupacji, mamy nawet jedną datę dzienną: $2 \mathrm{~V}$, ale konkretniejsze ustalenia zostają udaremnione przez sformułowania w rodzaju: [s. 276]

Dwa lata temu. Czy może dwanaście? Czas leci i stoi murem, na własnych pozycjach - jak Alianci.

Dlaczego już na schodach miała poczucie, jakby w tym wielobramnym ulu Niemcewicza 9 nie była od bardzo dawna? Naprawdę była w zeszłym tygodniu. Czasem miesiące umkna nie wiadomo kiedy, a czasem tydzień... Tak! Ale ten nowoczesny holik, schludny, tak dobrze znajomy, to na pozór wcale nie miejsce, w którym by chwile wykrzywiały się ni stąd, ni zowąd nienaturalnym, niesamowitym spokojem zatrzymanego czasu: streszczającego nagle zawartość lat. [s. 280]

W opowieści składającej się z ośmiu ponumerowanych części na pierwszy plan wysuwają się kolejne postaci: Tuśka, Wilczek, Dorota, Isia, Nula, Una i Łapcia. Zobrazowane zostały epizody ich aktywności konspiracyjnej, zyskujemy także momentalny dostęp do świata doznań i przeżyć. Co istotne dla sygnalizowanej tu fragmentaryczności, bohaterki Malewskiej ani nie mają, poza kilkoma enigmatycznymi aluzjami, przeszłości fabularnej (w sensie przekazanej czytelnikowi wiedzy o tym, kim były i co robiły wcześniej), ani też nie poznajemy ich późniejszych wojennych i powojennych losów. Narrator nie informuje o kończącym warszawską konspirację powstaniu, a ściślej mówiąc, pojawia się ono tylko tak, jak mogłyby myśleć o nim postaci utworu. Raz to jest niejasna sugestia w rozszyfrowywanym dokumencie, innym razem przeczucie bohaterki. Opowiadanie, choć powstałe po wojnie, nie wykracza swą perspektywą poza czas opisywanych zdarzeń. Co więcej, fabuła urywa się w momencie, gdy szyfrantki zgromadzone w zakonspirowanym lokalu czekają na jedną $z$ nich, która $z$ niewiadomych powodów jeszcze nie dotarła na miejsce. W tekście brak zatem zakończenia rozumianego jako dopowiedzenie wątków. Zamiast tego pojawia się kompozycyjna klamra stworzona przez informację, iż oto mamy do czynienia z powrotem do mieszkania, które na początku historii kobiety musiały opuścić.

Sens rozmycia czasowych i fabularnych konturów opowiadania można rozważać w dwu pozornie sprzecznych kontekstach. Po pierwsze, wyraźne jest poczucie, że chodzi o zapis doznań szczególnego rodzaju, nacechowanych niezwykle silnymi emocjami oraz powiązanych $z$ rezygnacją $z$ typowych ról wyznaczonych przez płeć (szyfrantki rozstają się $z$ rodzinami, jedna $z$ nich nie może odwiedzić swojego chorego dziecka, inna traci męża, który nie sprostał ciężarowi odpowiedzialności konspiracyjnej). Po drugie - z założenia nie jest to doświadczenie wykluczające. Wprost 
przeciwnie, należy uznać, iż zabiegi psychologizujące opowieść, w tym sygnalizowana wcześniej „temporalna dyslokacja” zdarzeń - jak określono taki typ zabiegów ${ }^{30}$ - łączą się z potraktowaniem kobiecej perspektywy jako perspektywy po prostu ludzkiej.

Sądzę, że warto tu odwołać się do - bliskiej Czystemu mieszkaniu - psychologicznej tradycji prozy Dwudziestolecia międzywojennego. Stosowane przez pisarkę zabiegi formalne, takie jak personalna konwencja bliskiego widzenia i związana $\mathrm{z}$ nią dominacja unaoczniających form narracji pochodzą $\mathrm{z}$ tego właśnie literackiego nurtu, reprezentowanego przez utwory m.in. Zofii Nałkowskiej, Marii Kuncewiczowej czy Jarosława Iwaszkiewicza. Specyfika owych zabiegów w opowiadaniu łączy się jednak $\mathrm{z}$ koniecznością adaptacji starych technik do - o czym wspomina Iwasiów - nowych sposobów „uczestnictwa w świecie, które otwiera trauma nowoczesnego pola bitwy obejmującego każdą możliwą przestrzeń" ${ }^{31}$. Patrząc na utwór $\mathrm{z}$ tej perspektywy, jesteśmy w stanie w owym rozmywaniu konturu fabularnego, w powtarzalności sytuacji okupacyjnych dostrzec - odnajdywany w wielu dziełach zaliczanych do kanonu modernistycznej prozy wojennej - zapis poczucia niezadomowienia w historii, mierzenie się „Z elementami "zamrożonego" czasu: straconej przeszłości; traumatycznej teraźniejszości; zniszczonej przyszłości””2.

W tym miejscu należy również odnieść się do sugerowanych przez Sulikowskiego zbieżności między dziełem Malewskiej a powstałym prawie dwie dekady później Pamiętnikiem z powstania warszawskiego Mirona Białoszewskiego (s. 20). To prawda, że oboje autorzy poszukiwali takich form zapisu, które byłyby adekwatne wobec „wielokształtności i osobliwości” ${ }^{33}$ doświadczeń wojennych. Jednak podobieństwa formalne wydają się tu raczej zewnętrzne. Pomijając już same różnice między rzeczywistościami okupacyjną i powstańczą, nie sposób też nie dostrzec odmienności sytuacji komunikacyjnych wpisanych w oba teksty. W wypadku utworu Białoszewskiego można mówić o bliskim formule oral history, skonstruowanym post factum ,zdarzeniu interpretacyjnym”, o autorskim świadectwie rozumianym jako „akt pamięci zależny zarówno od momentu, w którym się odbywa, jak i od historii, której dotyczy" ${ }^{4}$. Jak wiemy, Pamiętnik z powstania warszawskiego ma narracyjno-biograficzne centrum nie tylko usytuowane w punkcie zewnętrznym wobec czasu wojny, ale i ściśle wyznaczone:

Teraz mam czterdzieści pięć lat, po tych dwudziestu trzech latach, leżę na tapczanie cały, żywy, wolny, w dobrym stanie i humorze, jest październik, noc, 67 rok, Warszawa znów ma milion trzysta tysięcy mieszkańców ${ }^{35}$.

Wszelkie zaś kompozycyjno-stylistyczne zabiegi objawiające destrukcyjną moc wojny, takie jak asocjacyjny montaż, dekompozycja spójnych formuł językowych,

Zob. T. Armstrong, Modernism. A Cultural History. Cambridge-Malden, Mass., 2005, s. 19.

I. I w a s i ó w, Centralna płeć cywila. W zb.: Wojna. Doświadczenie i zapis. Nowe źródła, problemy, metody badawcze. Red. S. Buryła, P. Rodak. Kraków 2006, s. 404.

Armstrong, loc. cit.

Sławiński, op. cit., s. 9.

P. Filip kow s ki, Historia mówiona i wojna. W zb.: Wojna. Doświadczenie i zapis, s. 15.

M. Bi ł ł os zew ski, Pamiętnik z powstania warszawskiego. Wyd. 2. Warszawa 1971, s. 5-6. 
przełamywanie i wykolejanie związków składniowych, zostają zakotwiczone w nadrzędnej tożsamości narratora autorskiego, upodobnionego - chociażby ze względu na cechy języka - do podmiotu innych wypowiedzi literackich Białoszewskiego ${ }^{36}$. Należy zauważyć, że u Malewskiej sytuacja jest odmienna. Jak już zostało powiedziane, wyraźnie tam widzimy zarówno ucieczkę od biografii, jak i ograniczenie funkcji narratora w roli dysponenta sensów przypisanych utworowi jako całości na rzecz zwielokrotnionych punktów widzenia. Łączą się z tym różnice w sposobie wykorzystania „mowy skrótowej, "okaleczonej“” - jak ją określił Sulikowski (s. 20). W Pamiętniku z powstania warszawskiego język potoczny, motywowany pierwszoosobową narracją, stanowi rodzaj filtru, przez który zostają przepuszczone obrazy codziennych zmagań o przetrwanie ${ }^{37}$. W Czystym mieszkaniu nasycone specjalistycznym słownictwem, eliptyczne, ,zaszyfrowane” dialogi są najbardziej wyrazistym językowo miejscem ujawniania się aktywności konspiracyjnej bohaterek. Owe wypowiedzi, niejako „podsłuchane” przez odbiorce, stanowia zapis nakierowany na dotarcie do nieupozowanej przeszłości, która stawia opór próbom jej zrozumienia:

- Jedziemy, Łapcia?

- Jedziemy. W wilku rak kot.

- „W ślad”, bąk - odpowiedziała, przesunąwszy paski, Genowefa.

- W zerze siedem zero - obwieściła Tita pod lustrem.

Zaśmiecony już gruntownie salonik odnalazł znajomą melodię monotonnego czwórgłosu.

- W capie pies lis... - Depesza była na litery, w robocie zastępowane zwierzętami, a meldunek pocztowy na cyfry.

- Czy ci co wychodzi, Nula?

- Dotąd nie. W dwójce pięć cztery.

- Dorota przyszła? - od drzwi zabrzmiało zdyszane pytanie Wilczka.

- W dwójce sześć osiem... W kocie tur mysz... - zaszemrało zamiast odpowiedzi.

- Co masz? - podniosła głowę Una.

- Pierwsza godzina - stwierdziła Tita pod nosem. - W zerze dwa dwa.

- Te dalsze ciagi Komara, ale pisał, widzę, naszym nowym ołówkiem! - odważnie, grubym głosem zameldował Wilczek.

Jedna jedyna Nula nad kolumna obliczeń tak jakby zdołała się oderwać od rzeczywistości.

- Nie dyktuj mi, Tita. Bierz się lepiej do „od”, bo ja tu muszę naprzód dobrym końcem rozumu sama ruszyć.

- W dziku łoś łoś...

- W lisie „buka” żubr... [s. 347-348]

Ograniczona w porównaniu z Pamiętnikiem z powstania warszawskiego kolokwializacja języka utworu Malewskiej przekłada się też na bardziej stonowany zapis okropności wojny, który nigdzie nie jest aż tak drastyczny, jak choćby w znamiennych u Białoszewskiego scenach ekshumacji. U autorki Czystego mieszkania śmierć stanowi ciążące nad postaciami zagrożenie, rzadziej zostaje skonkretyzowana, jak we wspomnieniu jednej z bohaterek o zabitych przez Niemców dwu młodych

O podwojeniu ról narracyjnych w Pamiętniku z powstania warszawskiego, oddzieleniu tego, kto "gada”, od tego, kto „zapisuje”, zob. M. J a ni o n, Wojna i forma. W zb.: Literatura wobec wojny i okupacji, s. 230 .

37 Na temat światoobrazu konstruowanego przez zabiegi językowe Białoszewskiego zob. S. B a r a ńc z a k, Człowiek bezbronny. (O „Pamiętniku z powstania warszawskiego” Mirona Białoszewskiego). W zb.: jw. 
łączniczkach. Również obraz codzienności ma w opowiadaniu Malewskiej charakter bardziej wybiórczy. Przede wszystkim brakuje tu doświadczeń przynależnych do sfery cielesności i fizjologii. Choć, rzecz jasna, także Białoszewski ukazuje w tym zakresie znacznie mniej niż mógłby, to w Pamiętniku z powstania warszawskiego jest miejsce dla tak nieliterackich scen, jak np. korzystanie ze wspólnego wychodka, podczas gdy w opowiadaniu, owszem, pojawia się domowa ubikacja, jednak nie w przypisanej sobie roli, lecz jako skrytka dla papierów konspiracyjnych.

Zasadniczo różnią się też od siebie w obu utworach sposoby uczestniczenia postaci w historii. Białoszewski pozostawia podział na żołnierzy i cywilów, a główna zmiana polega na odwróceniu perspektywy - to nie ludność cywilna jest tłem dla powstańców, lecz rzecz skupia się na codzienności przetrwania. U Malewskiej sedno opowieści stanowi walka. Następuje tu jednak przesunięcie uwagi z militarnych działań mężczyzn na służbę kobiet, która, nie wymagając używania broni, jest tak samo istotna, jak akcje zbrojne, i z pewnością równie ryzykowna.

Ów obraz aktywizmu kobiecego, wymykającego się schematom męskich narracji o wojnie, stoi w wyrazistej opozycji wobec takich opowieści okupacyjno-powstańczych, jak Kamienie na szaniec Aleksandra Kamińskiego czy Kolumbowie. Rocznik 20 Romana Bratnego z ich romantycznymi stereotypami cnót militarnych i heroicznego męczeństwa. Sprawa przez duże „S”, oczywiście, nadal u Malewskiej istnieje, tyle tylko, że pisarka wypracowała dla jej ujęcia - dzięki odwołaniu do Norwidowskiego wzorca służby, a nie tyrtejsko-mickiewiczowskiego wzorca ofiary własny styl, uciekający zarówno od patosu, jak i od egzaltacji czy sentymentalizmu. Jedna $z$ cech owego stylu stanowią - odnajdywane na poziomie narracji i przytoczeń - chwyty komiczne oscylujące między łagodną ironią a czarnym humorem. Ich zadaniem nie jest obniżanie rangi działań konspiracyjnych, lecz oswajanie związanych z nimi zagrożeń.

Pisarka starała się również unikać wojennych schematów fabularno-biograficznych. To, co w okupacyjnych fabułach atrakcyjne i pociagajacce $z$ punktu widzenia masowego odbiorcy (akcje cichociemnych, efektowne ucieczki z konwojów czy odbijanie więźniów) ${ }^{38}$, pojawia się jedynie na marginesie opowieści Malewskiej, a i finały owych historii wydają się inne od oczekiwanych (skoczek przysłany ze Szkocji wpadł po zamachu, konspirator, który brawurowo zbiegł Niemcom, okazał się konfidentem i zginął od polskiej kuli). Nawet śmierć tych, którzy dostali się w niemieckie ręce, budzi przede wszystkim ulgę związaną $\mathrm{z}$ odsunięciem zagrożenia wsypą:

- Zaraz... a jak z Chlewikiem? O Batiarze wiadomości nie ma pan?

- O tym skoczku? Mam. Wykończyli go, nie sypnął nic.

- No to Chlewik tak jak czysty - ucieszyła się Lipka.

Przemówienie pogrzebowe... Ile to lat temu posłyszała Isia pierwsze podobne? I mówiła sobie wtedy, o, było się młodym: „...Czeka go pogrzeb z honorem wojskowym...” Nie tylko poległemu, ale kandydatom na to samo właściwie jest chyba wszystko jedno. [s. 334]

Najbliższy przygodowemu nurtowi okupacyjnych opowieści jest epizod z wy-

38 Podkreślmy tu przy okazji kwestię odległości dzielącej opowiadanie Malewskiej od współczesnych narracji kultury popularnej, które właśnie na tego typu atrakcjach fabularnych budują mit okupacyjno-konspiracyjny. 
niesieniem przez jedną z szyfrantek z mieszkania, będącego niemieckim kotłem, konspiracyjnego rekwizytu - żelazka $z$ umieszczoną w jego wnętrzu „bibuła”. Autorka czyni wszakże wiele, by pozbawić to zdarzenie aury sensacyjności. Przede wszystkim nie zyskuje ono samodzielnego narratorskiego przedstawienia, ponadto relacja bohaterki zostaje skonfrontowana $\mathrm{z}$ reakcjami innych postaci, krytycznie odnoszących się do jej ryzykanctwa. Co znamienne, jedyną osobą reagująca entuzjastycznie na tę samowolną akcję jest najmłodsza $z$ konspiratorek, 17-latka, dla której podziemna działalność stanowi jeszcze fascynujące pasmo przygód i wyzwań:

- Zosia wiedziała, że najgrubsze ryby muszą mieszkać jak zwykli ludzie, mimo to wyobrażała ich sobie za żelaznymi drzwiami otwieranymi jak w labiryncie z Faraona. Do tego komplet ślicznych kryptonimów łączących się rodzinami, jak w zielniku. No i wspominki: gdzie co było, gdzie się co stało, gdzie jaki swąd, gdzie jaki cynk, gdzie jak gorąco.

Żeby tak raz wypatrzyć z boku takiego na cynku. I ostrzec. Na przykład radiostację Jotów! Ci to dopiero mają fajne życie. [...]

$[\ldots]$

Albo żeby tak kiedyś być w dywersji. Jak tamta Zosia-,folksdojczka”, co szykowała zamach nawet w Berlinie. [s. 265]

Zamiast pochwały heroizmu ujmowanego w kategoriach militarno-żołnierskich Malewska odwołała się - używając słów Marii Janion - do „moralnej i tragicznej substancji życia"39. W tym kontekście warto wrócić do sygnalizowanego przez autorkę Czystego mieszkania - również w powojennej publicystyce - problemu ceny płaconej za okupacyjne zagrożenia, którą nie jest jedynie śmierć. Życie pod presją rodzi kryzysy przybierające różną postać, np. koszmarów nękających Unę:

- Ale Unie to śnią się takie rzeczy, że ch ciałaby umrzeć - tak napomknęła kiedyś Genowefa, kiedy mieszkały razem i opiekowała się Uną-rekonwalescentką. [s. 277]

- czy też narastającej nienawiści do świata, jak w przypadku Genowefy:

I Dorota teraz pojęła, dlaczego Una nie mogła z Genowefą wytrzymać. I czemu Genowefa powtarza teraz z taką niepotrzebną szewską pasją: - Słyszysz?! - Jakby brak odpowiedzi doprowadzał ją do ostateczności.

Ach, dawno już, okazuje się, przyszła na nią ta ostateczność, która od silnych nawet kobiet nie jest nigdy daleka. Ale dość słabe nawet kobiety potrafią ją potem znosić latami, nie zdradzając, jak bardzo nie są już sobą.

Na pewno była sobą, kiedy pielęgnowała Unę w chorobie. A pierwszym zjawiającym się tu Żabom przedstawiała swego męża z żartobliwie tajoną dumą, z jaką patrzy się na istoty kochane. Ale to było parę lat temu - potrójnych czy poczwórnych wojennych lat. [s. 280-281]

Ciśnienie, jakiemu poddawane są bohaterki, może zostać zneutralizowane np. przez głęboką wiarę. I ona jednak - jak dowodzi tego załamanie nerwowe, które przydarzyło się w pewnym momencie Łapci - nie chroni przed wszystkimi zagrożeniami psychicznymi. Wskazując więc na istotną w Czystym mieszkaniu potrzebę znalezienia oparcia w jakimś nadrzędnym wobec wojennej degradacji systemie aksjologicznym, należy odróżnić bezpośrednie rezonerstwo charakterystyczne dla 
wielu utworów pisanych z perspektywy katolickiej (przykładem mogą tu być choćby wojenne powieści Jana Dobraczyńskiego: Najeźdźcy czy W rozwalonym domu ${ }^{40}$ ) od subtelniejszej w tym względzie Malewskiej, której bohaterki odwołują się do świata wartości w perspektywie indywidualnych poszukiwań i odkryć, jak dzieje się w wypadku Nuli:

Szła ulicą tak czarną, że traciło się poczucie rzeczywistości, mówiąc sobie stanowczo, że wszystko jest nonsensem.

Nonsensem: czymś bez żadnej proporcji do człowieka. Bo i śmierć właściwie... O, bardziej niż co innego.

Próbowała czasem dawniej uprzytomnić sobie tę chwilę. Bo to będzie chwila, jakaś chwila: to jest ważne - więc jedna $z$ tych rozsypujących się, niezupełnych, nieuchwytnych. Bez punktu odniesienia. Choćbym wiedziała całkiem na pewno, że On jest, ten punkt odniesienia, tak jak wierzą Dorota i Łapcia - to zapomnę... - Bo chwila może być całkiem pusta, ta chwila - jakiś okropny niewypał czasu. Tu nie wystarczą żadne zwykłe środki, żadne mizerne codzienne „stawianie czoła”. [s. 301]

„Czy znajdziemy kobiety w tekście wojny?” - pytała w 2006 roku Iwasiów ${ }^{41}$. Kilka lat później w poszukiwaniu tych tropów Weronika Grzebalska sięgnęła do relacji z powstania warszawskiego ${ }^{42}$. Również w Czystym mieszkaniu, zaskakującym na tle całej twórczości Malewskiej, bohaterki mówią głosem własnym, a nie pożyczonym od mężczyzn ${ }^{43}$. I mimo że ta okupacyjna opowieść nie służy jakiejś radykalnej rewizji przeszłości (możemy ją za Grzebalską określić mianem „historii neotradycyjnej" ${ }^{44}$ ), to należy podkreślić, iż wymiar kobiecy konspiracji, pomijany w powojennej prozie jako margines doświadczenia okupacyjnego, staje się w niej pierwszym planem. Lecz czy dla losów tej, zapisanej w formie „babskiego gadania”, narracji, dotyczącej jednego z mniej znanych aspektów aktywności polskiego ruchu oporu, nie jest znamienny również fakt, że drogę do czytelnika odnalazła ona dopiero ponad pół wieku od czasu ukończenia, a więc wtedy, gdy męski obraz doświadczeń wojennych przestał być już traktowany jako - w sposób oczywisty - uniwersalny?

Trzeba jednak zauważyć, że drugi z wymienionych utworów zyskał na łamach „Tygodnika Powszechnego" (1946, nr 45) pozytywne recenzje autorstwa I. Sławińskiej (Rozwalony i odbudowany dom) oraz właśnie H. Male w sk i e j (Jeszcze o „Rozwalonym domu”).

$41 \quad$ I wa siów, Centralna płeć cywila, s. 399.

42 W. Grzebals ka, Płeć powstania warszawskiego. Warszawa 2013.

43 O zapożyczonym przez piszace (i czytające) kobiety „męskim” głosie uniemożliwiającym wyrażenie ich własnych opowieści pisała S. Felman w pracy What Does a Woman Want? Reading and Sexual Difference (Baltimore, Md., 1993, s. 13-14).

W. G rz e b a ls k a, Od fałszywego uniwersalizmu do fetyszyzacji różnicy. Historia powstania warszawskiego i rewizjonistyczny „zwrot herstoryczny”. „Pamięć i Sprawiedliwość” 2015, nr 2. Badaczka wyróżniła trzy odmiany nowego historycznego dyskursu, poza neotradycyjnym - także historię równoległą oraz nurt genderowy. Cel pierwszego $z$ nich stanowi właśnie poszerzanie dziejów narodu o losy nie docenianych dotąd bohaterek kobiecych. W drugim przypadku chodzi o wpisanie w ramy historyczne również „sfer życia, które nie sa przedmiotem zainteresowania klasycznej historiografii i które tradycyjnie postrzega się jako "kobiece«: macierzyństwa, miłości, mody i urody czy kulinariów, a nawet przemocy seksualnej" (ibidem, s. 152). Wreszcie historia genderowa uwzględnia „politykę płci - a więc ogół zabiegów kształtujących wzory męskości i kobiecości oraz relacje między płciami - która służyła jako narzędzie mobilizacji społeczeństwa do określonych celów oraz wytwarzania i legitymizacji danego porządku społecznego" (ibidem, s. 154). 


\author{
Abstract \\ ALEKSANDRA CHOMIUK Maria Curie-Skłodowska University, Lublin \\ ORCID: 0000-0002-3236-615X
}

\title{
A DIFFERENT WAR STORY HANNA MALEWSKA'S "CZYSTE MIESZKANIE” (“CLEAN HOUSE”)
}

The paper refers to Hanna Malewska's short story on the Warsaw II World War Underground. The piece, which shifts interest from sequence of events to a record of traumatic experience of an individual under occupation, is linked to a formula of characteristic of the woman writer's camouflaged autobiography. The fundamental writing mode is the creation of few literary roles rewritten as a multidimensional "collected picture" of women conspirators. The most crucial reading trope is connected to displaying a woman style of actions and conspiracy experience complemented with unilateral male war history. At the same time, borderline situations of threat, fear, solidarity and responsibility included into the story are such ones of which a woman perspective of experience in the piece become a simply human perspective. 